\title{
Praktik Bagi Hasil Pengelolaan Lahan Perkebunan Kelapa Sawit pada Koperasi Cempaka Biru Kecamatan Sejangkung Kabupaten Sambas Perspektif Hukum Islam
}

\author{
Zarul Arifin \\ Institut Agama Islam (IAI) Sultan Muhammad Syafiuddin Sambas \\ Zarularifin89@gmail.com
}

\begin{tabular}{l|l|l}
\hline Received: 03 Januari 2020 & Revised: 23 Maret 2020 & Approved: 28 April 2020 \\
\hline
\end{tabular}

\begin{abstract}
This research is motivated by the practice of profit sharing in the management of land by cooperatives in the absence of time clarity in the distribution of results carried out by cooperatives to their members. Islam towards the practice of sharing the results of land management by the Cempaka Biru Cooperative in the Sejangkung District. This type of research is a type of descriptive qualitative research that is Field Research (field research). The study uses a normative sociological approach. The data source in this study uses primary data taken from the cooperative chairman, treasurer and cooperative members. Whereas the secondary data sources are books, mass media and the Law. Data collection techniques used were observation techniques, interview techniques, and documentation techniques. Based on the results of the study, the researchers concluded that the practice of sharing the results of land management by the Cempaka Biru Cooperative did not violate Law No. 25 of 1992 article 45 concerning Remaining Results of Operations, because basically the residual results of cooperative efforts are cooperative income obtained in one fiscal year. In the analysis according to the perspective of Islamic law the profit-sharing in the Cempaka Biru Cooperative is called the profit sharing of the Musaqah plantation estate or mukhabarah. But the practice of sharing the results of land management by the Cempaka Biru Cooperative in the District of Sejangkung is prohibited by syara 'because of the existence of a contract containing the element of gharar (uncertainty) so that it is prohibited by syara'.
\end{abstract}

Keywords: Profit sharing, plantation land management, Islamic law

\begin{abstract}
Abstrak
Penelitian ini dilatarbelakangi bahwa praktik bagi hasil dalam pengelolaan lahan oleh koperasi adanya ketidak jelasan waktu dalam pembagian hasil
\end{abstract}


yang dilakukan oleh koperasi kepada anggotanya.. Adapun penelitian ini bertujuan untuk mengkaji bagaimana sistem bagi hasil dalam pengelolaan lahan oleh Koperasi Cempaka Biru di Kecamatan Sejangkung dan meninjau Hukum Islam terhadap praktik bagi hasil pengelolaan lahan oleh Koperasi Cempaka Biru Kecamatan Sejangkung. Adapun jenis penelitian ini adalah jenis penelitian kualitatif deskriptif yang bersifat Field Research (penelitian lapangan). Penelitian menggunakan pendekatan sosiologis normatif. Sumber data pada penelitian ini menggunakan data primer yang diambil dari ketua koperasi, bendahara dan anggota koperasi. Sedangkan sumber data sekunder yaitu, buku-buku, media massa dan UndangUndang. Teknik pengumpulan data yang dilakukan adalah teknik observasi, teknik wawancara, dan teknik dokumentasi. Berdasarkan hasil penelitian, peneliti menyimpulkan bahwa praktik bagi hasil pengelolaan lahan oleh Koperasi Cempaka Biru tidak melanggar Undang-Undang No. 25 Tahun 1992 pasal 45 tentang Sisa Hasil Usaha, karena pada dasarnya sisa hasil usaha koperasi merupakan pendapatan koperasi yang diperoleh dalam satu tahun buku. Dalam analisis menurut perspektif hukum Islam bagi hasil di Koperasi Cempaka Biru disebut bagi hasil lahan perkebunan Musaqah atau mukhabarah. Namun praktik bagi hasil pengelolaan lahan oleh Koperasi Cempaka Biru di Kecamatan Sejangkung dilarang oleh syara' karena adanya salah satu akad yang mengandung unsur gharar (ketidakpastian) sehingga dilarang oleh syara'.

Kata Kunci: Bagi hasil, pengelolaan lahan perkebunan, hukum Islam

\section{Pendahuluan}

Islam sebagai agama yang sempurna, mengatur segala aspek kehidupan manusia secara menyeluruh yaitu hubungan manusia dengan Allah SWT (bablu min Allab) diatur dalam bidang ibadah yang menyangkut dengan kehidupan akhirat dan hubungan secara timbal balik atau lebih sederhananya yaitu hubungan antara seseorang dengan orang lain (bablu min an-nas) dalam pergaulan hubungan dunia atau bisa juga disebut sebagai kegiatan muamalah. ${ }^{1}$

Dalam hal ini adalah menyangkut masalah pemenuhan kebutuhan hidup manusia. Pemenuhan kebutuhan, tidak mungkin diproduksi sendiri oleh individu yang bersangkutan, dengan kata lain ia harus bekerjasama dan saling membantu dengan orang lain. ${ }^{2}$ Itulah mengapa manusia disebut sebagai makhluk sosial, karena pada dasarnya manusia tidak dapat hidup sendiri.

Untuk memenuhi kebutuhan hidupnya, manusia juga harus berusaha mencari karunia Allah dengan cara bekerja agar mendapatkan apa yang ada dimuka bumi ini sebagai sumber ekonomi. Perintah bekerja disebutkan dalam QS An-Naba' ayat 11 yang berbunyi:

${ }^{1}$ Amir Syarifuddin, Garis-garis Besar Fiqhi, (Jakarta: Kencana, 2013), h. 174

${ }^{2}$ Suhrawardi K. Lubis, Hukum Ekonomi Islam, (Jakarta: Sinar Grafika, 2000), h. 4. 


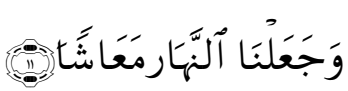

Kami telah membuat waktu siang untuk mengusahakan kehidupan. ${ }^{3}$

Ayat-ayat di atas merupakan prinsip-prinsip dalam bermu'amalah, di dalam hukum Islam yang menggambarkan bahwa Islam mengatur dan melindungi masing-masing pihak yang melakukan akad kerjasama, agar tidak terjadi saling merugikan satu sama lainnya sehingga dapat tercapai tujuan dari akad tersebut.

Banyak pekerjaan yang dilakukan oleh manusia, salah satunya adalah pada sektor pertanian. Pertanian merupakan salah satu sektor yang masih potensial untuk digarap dalam rangka untuk memenuhi kebutuhan manusia, pada sektor ini manusia banyak menggantungkan hidupnya untuk memenuhi kebutuhan hidup. Pekerjaan bertani dijelaskan dalam QS Yasin ayat 33-35:

Dan suatu tanda (kekuasaan Allah yang besar) bagi mereka adalah bumi yang mati. Kami bidupkan bumi itu dan Kami keluarkan dari padanya biji-bijian, Maka daripadanya mereka makan. Dan Kami jadikean padanya kebun-kebun kurma dan anggur dan Kami pancarkan padanya beberapa mata air, supaya mereka dapat Makan dari buabnya, dan dari apa yang diusahakan oleh tangan mereka. Maka Mengapakah mereka tidak bersyukur?". 4

Pertanian merupakan aktivitas manusia untuk menghasilkan produk yang berasal dari tumbuh-tumbuhan. ${ }^{5}$ Ada sebagian masyarakat yang memiliki ilmu dalam bidang pertanian tetapi tidak memiliki lahan pertanian untuk digarap, dan sebaliknya ada sebagian masyarakat yang mempunyai lahan tanah yang dapat dimanfaatkan untuk pertanian maupun perkebunan tetapi tidak menggarap tanah tersebut, sehingga tanah tersebut tidak produktif. ${ }^{6}$

Kerjasama di bidang penggarapan tanah terjadi karena masing-masing pihak saling memerlukan. Ada sebagian masyarakat memiliki tanah tetapi tidak mampu dan tidak memiliki ilmu untuk menggarap lahan yang dimiliki. Kemudian ada sebagian masyarakat yang memanfaatkan lahan kosong yang tidak produktif tersebut untuk digarap dan menghasilkan produk-produk tanaman yang dapat dijual dan menghasilkan uang. Kegiatan muamalah pada penggarapan tanah biasanya dilakukan dengan cara bagi hasil antara pemilik tanah dengan penggarap tanah. Praktik kerjasama bagi hasil dalam pertanian taupun perkebunan merupakan bentuk pemanfaatan tanah yang tidak produktif

${ }^{3}$ Ibid. h. 582

${ }^{4}$ Departemen Agama RI, al-Qur'an dan Terjemahnya, (Diponegoro: Al- Hikmah, 2010), h. 442

${ }^{5}$ Zaki Fuad Chalil, Pemerataan Distribusi Kekayaan dalam Ekonomi Islam, Jakarta: Erlangga, 2009), h. 270

${ }^{6}$ Munir dan Sudarsono, Dasar-Dasar Agama Islam, (Jakarta: Rineka Cipta, 2001), h. 226 
digarap ditanami tanaman-tanaman yang menghasilkan nilai jual, untuk pembagian bagi hasil terdapat dua unsur yang harus dipenuhi, yaitu modal dan kerja dilakukan menurut perbandingan tertentu dari hasil tanah yang digarap, jumlah bagi hasil ditentukan bersama pada saat akad berlangsung.

Kegiatan bekerja dan berusaha sangat dipengaruhi oleh kondisi dimana masyarakat itu bertempat tinggal. Di desa pada umumnya sebagian besar masyarakat bekerja pada sektor pertanian ataupun perkebunan, pertanian biasanya dilakukan dengan menanam tanaman yang menjadi sumber bahan pokok makanan masyarakat tersebut, kebetulan sebagian besar masyarakat Indonesia mengkonsumsi nasi, maka tanaman yang ditanam banyak padi. Walaupun ada juga sebagian masyarakat Indonesia lainnya yang mengkonsumsi makanan pokok jenis lainnya. Ada juga sektor pertanian yang bergerak di bidang penanaman sayur yang menjadi komoditas unggulan suatu daerah. Usaha perkebunan banyak dilakukan oleh masyarakat di desa dengan menanam tanaman keras seperti menanam kelapa, karet, kelapa sawit, dan jenis-jenis tanaman keras lainnya. Panen biasanya di lakukan setiap buah siap di panen, tergantung jenis tanaman yang ditanam.

Seperti di kecamatan Sejangkung Kabupaten Sambas yang menjadi lokasi penelitian ini umumnya masyarakat bergerak di bidang pertanian dan perkebunan. Hal ini dikarenakan struktur wilayahnya yang sangat sesuai dengan tanah yang luas dan sinar matahari yang hampir sepanjang tahun ditunjang dengan sumber air yang baik karena wilayah ini dilintasi oleh sungai besar dimana sungai ini merupakan alternatif utama menuju perkebunan tersebut.

Ada pun bentuk perkebunan ini adalah perkebunan kelapa sawit. Penanaman kelapa sawit sendiri dilakukan secara bertahap, di mana dimulainya penanaman pada tahun 2009. Total luas lahan mencapai 472 hektar dan sekitar 456 hektar digunakan untuk penanaman kelapa sawit dan sisanya digunakan untuk infrastruktur jalan dan parit dimana setiap 1 hektar terdiri dari 140 batang kelapa sawit.

Perkebunan kelapa sawit ini merupakan perkebunan kerja sama dengan sistem bagi hasil yang dikelola oleh sebuah koperasi. Adapun nama koperasi ini adalah Koperasi Serba Usaha Cempaka Biru atau biasa di sebut koperasi CB yang didirikan pada tanggal 3 September tahun 2009 dengan jumlah anggota 216 anggota.

Setiap anggota merupakan orang yang telah berkeluarga dengan kartu keluarga rata-rata di bawah tahun 2009. Meskipun koperasi ini telah lama berdiri tetapi koperasi ini benar-benar beroperasi sekitar pada tahun 2015. Pada tahuntahun sebelumnya koperasi ini memang sudah beroperasi hanya saja tidak seefektif sekarang. 
Dahulu tepatnya pada tahun 2015 ke bawah anggota sulit untuk menerima hasil dari penjualan kebun kelapa sawit dikarenakan koperasi selalu menanggung kerugian, yang katanya kerugian tersebut untuk membayar hutang, tetapi anggota tidak pernah menerima rincian dari setiap transaksi yang dilakukan oleh koperasi, tetapi hal ini telah tertangani dengan penggantian pengurus koperasi yang baru yang dilakukan oleh anggota koperasi. Untuk waktu penerimaan bagi hasil sisa usaha koperasi dengan anggota adalah setiap tiga bulan sekali, waktu ini telah disepakati semua anggota, tetapi nyatanya waktu penerimaan tidak tetap, kadang kurang dari tiga bulan dan kadang lebih dari tiga bulan.

Mengenai permasalahan yang dibahas dalam penelitian ini adalah sebagai berikut: Bagaimana praktik bagi hasil pengelolaan lahan oleh Koperasi Cempaka Biru di Kecamatan Sejangkung? Bagaimana Tinjauan hukum Islam terhadap praktik bagi hasil yang dilakukan oleh Koperasi Cempaka Biru Kecamatan Sejangkung?

Adapun jenis penelitian ini adalah jenis penelitian kualitatif deskriptif yang bersifat Field Research (penelitian lapangan). Penelitian menggunakan pendekatan sosiologis normatif. Pendekatan yang digunakan dalam penelitian ini adalah pendekatan sosiologis empiris adalah usaha mendekati masalah yang diteliti dengan sifat hukum yang nyata atau sesuai dengan kenyataan yang hidup alam masyarakat. Pendekatan sosiologis empiris harus dilakukan di lapangan dengan menggunakan metode dan teknik penelitian lapangan dengan mengadakan kunjungan kepada masyarakat dan berkomunikasi dengan para anggota masyarakat. Sumber data pada penelitian ini menggunakan data primer yang diambil dari ketua koperasi, bendahara dan anggota koperasi. Sedangkan sumber data sekunder yaitu, buku-buku, media massa dan Undang-Undang. Teknik pengumpulan data yang dilakukan adalah teknik observasi, teknik wawancara.

\section{Pembahasan}

\section{Bagi Hasil dalam Pertanian dan Perkebunan}

Prinsip kerjasama (akad) dalam Ekonomi Islam yang banyak dikenal adalah prinsip bagi hasil. Pertanian sebagai bidang yang bergerak di sektor riil, juga tak luput dari adanya prinsip kerjasama bagi hasil. Sehingga dengan adanya kerjasama dengan prinsip bagi hasil, kedua belah pihak dapat melakukan sebuah system kerjasama yang saling menguntungkan dengan memberdayakan lahan pertanian dan perkebunan tersebut. Banyak bentuk kerjasama (mu'amalah) yang dianjurkan dalam Islam, 
yang menekankan pada prinsip bagi hasil (profit sharing) antara lain: musyarakah, mudharabah, murabahah, muzara'ah dan musaqah. ${ }^{7}$

Pada prinsipnya Islam membolehkan semua bentuk kerja sama, selama kerja sama tersebut saling mendatangkan maslahat yang baik, terhadap dirinya dan masyarakat banyak pada umumnya, begitu banyak halnya dengan sistem bagi hasil pengelolaan lahan oleh koperasi cempaka biru'. Menurut Hukum Islam bagi hasil lahan pertanian dibagi dalam beberapa bagian, sebagai berikut:

\section{Musaqah}

Secara etimologi musaqah adalah bentuk kata yang mengikuti wazan (musaqiya) dari kata (asy-syaqi) yang memiliki arti penyiraman. ${ }^{8}$ Secara terminologi musaqqah adalah akad untuk pemeliharaan tanaman (pertanian) dan yang lainnya dengan syarat-syarat tertentu. ${ }^{9}$

Menurut syara' pengertian musaqab adalah penyerahan pohon kepada orang yang menyiramnya dan menjanjikannya, bila sampai buah masak dia akan diberi imbalan buah dalam jumlah tertentu. Dalam definisi lain juga menyebutkan bahwa musaqah ialah kerjasama antara pemilik kebun dan penggarapnya, sehingga kebun tersebut menghasilkan sesuatu. Hasilnya menjadi milik kedua belah pihak berdasarkan perjanjian yang telah disepakati. ${ }^{10}$

Ulama Syafi'iyah mendefinisikannya pemilik lahan mempekerjakan orang lain (petani) untuk mengelola kurma atau pohon anggur saja dengan mengairi dan merawatnya dengan ketentuan hasil kurma dan anggur itu menjadi milik berdua. ${ }^{11}$

1. Hukum Musaqah

Hukum musaqah terdiri dari dua macam yaitu;

a. Hukum Musaqab Shabih. Menurut ulama Hanafiyah hukum musaqah shahih apabila; Segala pekerjaan yang berkenaan dengan pemeliharaan pohon diserahkan kepada penggarap, sedang biaya yang diperlukan dalam pemeliharaan dibagi dua, hasil dari musaqah dibagi berdasarkan kesepakatan, jika pohon tidak menghasilkan sesuatu, keduanya tidak mendapatkan apaapa, akad adalah lazim dari kedua belah pihak, pemilik boleh memaksa

${ }^{7}$ Miftahul Jannah, Isna yuningsih, Rabiatul Adawiyah, Jurnal Ekonomi Mulawarman Vol 3, No. 4 Tahun 2018, Pengaruh Sistem Bagi Hasil Perkebunan Kelapa Sawit Terhadap Kesejahteraan Masyarakat (Studi di Desa Tengin Baru Kecamatan Sepaku Kabupaten Penajam Paser Utara)

${ }^{8}$ Husain Al Habsyi, Kamus Al-kautsar(Arab-Indonesia), (Surabaya:.Assegaff, 1977), h. 184.

${ }^{9}$ Abdul Rahman Ghazali, Fqih Muamalat, (Jakarta: Kencana, 2010), h. 119-120.

${ }^{10}$ H.Minhajuddin, Fikih Mu'amalah dalam Islam, (Makassar: Alauddin University Press, 2011), h. 214.

${ }^{11}$ Abdi Widjaya, Konfigurasi Akad dalam Islam, (Makassar : Alauddin University Press,2014), h.104. 
penggarap untuk bekerja kecuali ada uzur, boleh menambah hasil dari ketetapan yang telah disepakati, penggarap tidak memberikan musaqah kepada penggarap lain kecualidiizinkan oleh pemilik.

b. Hukum Musaqah Fasid. Musaqah fasid adalah akad yang tidak memenuhi persyaratan yang telah disepakati syara'. Menurut ulama Hanafiyah, musaqah fasid apabila: Mensyaratkan pemilik untuk ikut dalam penggarapan, Mensyaratkan kepada penggarap untuk terus bekerja setelah habis waktu akad, Musaqah digarap oleh banyak orang sehingga penggarap membagi lagi kepada penggarap lainnya. ${ }^{12}$

Rukun Musaqah: Shigat, dua belah pihak, kebun,masa kepemilikan, buah. ${ }^{13}$ Syarat-Syarat Musaqah yaitu ahli dalam akad, menjelaskan bagian penggarap, membebaskan pemilik dari pohon, hasil dari pohon dibagi antara dua orang yang melangsungkan akad, sampai batas akhir. ${ }^{14}$

\section{Muzara'ah}

Menurut etimologi mu₹ara'ah adalah bentuk kata yang mengikuti wazan mufa'alah dari kata dasar al-zar'u yang berarti al-inbat (menumbuhkan). ${ }^{15}$ Pengertian yang pertama merupakan arti majaz, sedangkan pengertian yang kedua adalah makna hakiki. Oleh karena itu terdapat larangan seorang manusia mengucapkan saya telah menumbuhkan, hendaklah ia mengucap kan saya bertani. ${ }^{16}$ Sebagaimana Firman Allah SW'T dalam QS Al-waqiah ayat 63-64.

\section{Maka terangkanlah kepadaku tentang yang kamu tanam?.Kamukab yangmenumbubkannya ataukah kami yang menumbubkan nya"? ${ }^{17}$}

1. Rukun dan Syarat Muzara'ah

Rukun muгara'a ${ }^{18}$ Jumhur ulama menetapkan rukun dan syarat yang harus dipenuhi, agar akad muzara'ah itu menjadi sah, yaitu: Ijab kabul (akad), penggarap dan pemilik tanah (aqid), adanya obyek (ma'qud ilaib).

Syarat muzara'ah menurut Abu Yusuf dan Muhammad yaitu, muzara'ah memiliki beberapa syarat yang berkaitan dengan aqid, tanaman, tanah yang ditanami, tanaman yang dihasilkan, alat bercocok tanam, dan waktu bercocok tanam. Syarat tanaman diantara para ulama terjadi perbedaan pendapat tetapi kebanyakan menganggap lebih baik jika diserahkan kepada pekerja.

${ }^{12}$ Azharudi Latift, Fiqhi Muamalat, (Jakarta: Kencana, 2010), h. 119.

${ }^{13}$ Sulaiman Rasyid, Fiqh Islam (Hukum Fiqh), Jakarta: Sinar Baru, 1994), h. 301.

${ }^{14}$ Rachmat Syafei, Fiqhi Muamalah.., h. 214.

${ }^{15}$ Atabik Ali Ahmad Zuhdi Muhdlor, Kamus Kontemporer, (Yogyakarta: Yayasan Ali Maksum Krapyak Yogyakarta, 1999), h. 1875.

${ }^{16}$ Abdur Rahman al-Jaziri, Fiqh Empat Mazhab, Terj.Moh. Zuhri, Jakarta: Pustaka AlKautsar, ), h.15 2010), h. 536

${ }^{17}$ Departemen Agama RI, al-Qur'an dan Terjemahnya, (Diponegoro: Al- Hikmah,

${ }^{18}$ Nasroen Haroen, Fiqh Muamalah, (Jakarta: Gaya Media Pratama, 2000), h. 115 
Syarat lahan garapan lahan memungkinkan untuk digarap, yakni apabila ditanami tanah tersebutkan menghasilkan, jelas lahannya ada penyerahan lahan, syarat-syarat tanaman yang dihasilkan, jelas ketika akad, diharuskan atas kerjasama dua orang yang berakad, ditetapkan persentase hasil pertanian diantara keduanya, hasil dari tanaman harus menyeluruh diantara dua orang yang melangsungkan akad.

\section{Mukhabarah}

Mukhabarah adalah bentuk kerjasama antara pemilik tanah dan petani dengan perjanjian bahwa hasilnya akan dibagi antara keduanya menurut kesepakatan bersama, sedangkan biaya dan benihnya dari penggarap tanah. ${ }^{19}$

Demikian juga dalam masalah mukhabarah tentulah ada unsur-unsur (rukun) yang dapat menyebabkan sahnya suatu perjanjian mukhabarah, dalam hal ini ulama' berbeda pendapat dalam menetapkan rukun-rukun tersebut pendapat itu antara lain:

1. Menurut Ulama Hanafiyyah

Menurut ulama Hanafiyyah adalah ijab dan qabul.Yaitu pemilik lahan berkata kepada pihak penggarap "Aku serahkan lahan ini kepadamu sebagai mukhabarah dengan upah sekian". Lalu pihak penggarap berkata, "Aku terima" atau "Aku setuju" atau perkataan-perkataan yang menunjukkan bahwa ia menerima dan menyetujuinya.

Apabila ijab dan qabul ini sudah terjadi, maka berlakulah akad almukhabarah diantara keduanya. Akan tetapi, sebagian ulama Hanafi menyatakan bahwasanya rukun mukhabarah ada 4 macam: Ada tanah yang dikelola, pekerjaan yang dilakukan pengelola, benih, alat pertanian.

2. Menurut Ulama Hanabilah

Ulama Hanabilah berpendapat bahwa mukhabarah tidak memerlukan qabul secara lafadz, tetapi cukup dengan mengerjakan tanah, itu sudah termasuk qabul. Selain rukun yang disebutkan di atas ada pula syarat dari mukhabarah, yaitu: Pemilik kebun dan penggarap harus orang yang baligh dan berakal. Benih yang ditanam harus jelas dan menghasilkan, jelasa batasnya, dan diserahkan sepenuhnya kepada penggarap. Pembagian untuk masing-masing harus jelas penentuannya. Jangka waktu harus jelas menurut kebiasaan. ${ }^{20}$

\footnotetext{
${ }^{19}$ Abdul Rahman Ghazali, Fiqih Muamalat, Jakarta: Kencana Prenada Media Group, 2010), h. 391.

${ }^{20}$ Muhammad Nurhadi "Syarat Mukhabarah". 2015(online), (Https: // muhammadnurhadi.wordpress.com), diakses tanggal 29 Desember 2019.
} 


\section{Berakhirnya Akad Musaqah, Muzaraah dan Mukhabarah}

Jangka waktu yang disepakati berakhir. Akan tetapi, apabila jangka waktunya sudah habis, sedangkan hasil pertanian itu belum layak panen, maka akad itu tidak dibatalkan sampai panen dan hasilnya dibagi sesuai dengan kesepakatan bersama di waktu akad. Oleh sebab itu, dalam menunggu panen itu, menurut jumhur ulama, petani berhak mendapatkan upah sesuai dengan upah minimal yang berlaku bagi petani setempat. Selanjutnya, dalam menunggu masa panen itu biaya tanaman, seperti: pupuk, biaya pemeliharaan, dan pengairan merupakan tanggung jawab bersama pemilik tanah dan petani, sesuai dengan presentasi pembagian masing-masing. Apabila salah seorang yang berakad wafat. Adanya udzur salah satu pihak, baik dari pemilik tanah maupun dari pihak petaniyang menyebabkan mereka tidak boleh melanjutkan akad mukbabarah itu. Uzur dimaksud antara lain adalah: Pemilik tanah terbelit utang, sehingga tanah pertanian itu harus ia jual, karena tidak ada harta lain yang dapat melunasi utang itu. Pembatalan ini harus dilaksanakan melalui campur tangan hakim. Akan tetapi, apabila tumbuh-tumbuhan itu telah berbuah, tetapi belum layak panen, maka tanah itu tidak boleh dijual sampai panen. Adanya uzur petani, seperti sakit atau harus melakukan suatu perjalanan keluar kota sehingga ia tidak mampu melaksanakan pekerjaannya. ${ }^{21}$

Hikmah musaqah, muzaraah, dan mukhabarah adalah terwujudnya kerjasama yang saling menguntungkan antara pemilik tanah dengan petani penggarap. Meningkatnya kesejahteraan masyarakat Tertanggulanginya kemiskinan. Terbuka lapangan pekerjaan, terutama bagi petani yang memiliki kemampuan bertani tetapi tidak memiliki tanah garapan.

\section{Praktik bagi hasil pengelolaan lahan oleh Koperasi Cempaka Biru di Kecamatan Sejangkung.}

Untuk mengetahui lebih dalam tentang bagi hasil pengelolaan lahan oleh Koperasi Cempaka Biru maka peneliti melakukan wawancara dengan 7 informan yang dianggap dapat memberikan informasi yang jelas dan sesuai dengan keinginan peneliti, adapun yang menjadi data wawancara peneliti sebagai berikut:

1. Informan I

Hari pertama dan orang pertama peneliti melakukan wawancara kepada bapak Santos. ${ }^{22}$ Selaku ketua koperasi, bapak santos kini berusia 36 tahun dan bekerja sebagai petani. Bapak Santos ini merupakan pelaksana tugas (PIT) di koperasi yang telah berlangsung 10 bulan, awalnya dia menepati posisi sebagai sekretaris koperasi hanya saja ketika ketua koperasi meninggal dunia dia langsung diangkat sebagai PIT ketua koperasi.

\footnotetext{
${ }^{21}$ Nasroen Haroen, Fiqh Muamalah ..., h. 280-281.

${ }^{22}$ Wawancara dengan Bapak Santos selaku ketua koperasi Cempaka Biru . Tanggal 5 Desember 2019.
} 
Peneliti memberikan pertanyaan pertama kepada Bapak Santos selaku ketua koperasi tentang bagaimana sistem kesepakatan dan cara pembagiannya, menurut Bapak Santos sistem kesepakatan yang telah dilakukan dengan anggota koperasi, anggota harus memberika kepercayaan penuh kepada pengurus koperasi dalam pengelolaan lahan guna untuk mengembangkan lahan tersebut. Sedangkan cara pembagiannya sendiri setiap akan melakukan pembagian hasil pihak koperasi akan mengadakan rapat kepada pengurus setiap kelompok guna untuk membahas hasil yang didapat koperasi serta pembagian jumlah yang akan diterima setiap anggota.

\section{Informan II}

Selanjutnya peneliti mengajukan pertanyaan kepada Bapak Dewan23 selaku bendahara koperasi. Bapak Dewan yang kini berusia 54 tahun dan bekerja sebagai petani sudah 3 tahun menjadi bendahara koperasi yang memegang uang simpanan pokok para anggota. Peneliti mengajukan pertanyaan kepada Bapak Dewan tentang bagaimana sistem bagi hasil yang dilakukan koperasi kepada anggotanya. Beliau menjawab bahwa setiap kali akan melakukan bagi hasil maka pihak koperasi akan melakukan rapat dengan setiap pengurus kelompok, dimana rapat ini bertujuan untuk memberitahu pada setiap kelompok jumlah yang diterima oleh koperasi selama kurun waktu 3 bulan. Beliau juga menjelaskan bahwa anggota bisa meminjam uang tetapi dengan syarat tidak terlalu besar jumlahnya dan jangka waktu yang tidak terlalu lama, paling tidak 3 bulan pinjaman tersebut harus sudah dikembalikan jika anggota yang meminjam uang tidak dapat mengembalikan pinjaman kepada koperasi maka ketika pembagian bagi hasil pihak koperasi akan memotong bagiannya sebesar jumlah yang dipinjamnya.

\section{Informan III}

Selanjutnya informan ke 3 adalah Bapak Saptudin ${ }^{24}$ selaku anggota koperasi yang sekarang berusia 56 tahun beliau bekerja sebagai karyawan di salah satu perusahaan yang ada di hulu kampung tempat beliau tinggal. Kedudukan Bapak Saptudin di koperasi adalah sebagai pengawas. Peneliti mengajukan pertanyaan kepada Bapak Saptudin seputar sistem bagi hasil yang dilakukan perusahaan kepada anggotanya, beliau menjawab bahwa bagi hasil sendiri dilakukan ketika pihak koperasi telah menerima hasil bersih tandan buah segar yang dikelola langsung oleh perusahaan, kurang lebih dalam kurun waktu 3 bulan, setelah itu baru pihak koperasi.

${ }^{23}$ Wawancara dengan Bapak Dewan selaku bendahara koperasi Cempaka Tanggal 5 Desember 2019.

${ }^{24}$ Wawancara dengan Bapak Saptudin selaku pengawas koperasi Cempaka Biru. Tanggal 09 Desember 2019. 


\section{Informan IV}

Informan selanjutnya bernama Bapak Bastian, ${ }^{25}$ Bapak Bastian ini berumur 46 tahun dan bekerja sebagai petani. Beliau salah satu anggota koperasi. Peneliti mengajukan pertanyaan seputar berapa hasil yang diterima oleh setiap anggota ketika bagi hasil berlangsung. Beliau menjawab besar jumlah yang diterima anggota koperasi tidak tetap sesuai perolehan yang didapat koperasi dari hasil penjualan tandan buah segar jadi berapa jumlah yang akan didapat anggota tidak bisa diprediksikan jumlahnya dan pembagiannya tidak dilakukan setiap bulannya melainkan paling tidak tiga bulan sekali.

5. Informan $\mathrm{V}$

Informan selanjutnya bernama bapak Karnan, ${ }^{26}$ bapak Karnan sendiri merupakan seorang petani yang berusia 34 tahun. Peneliti mengajukan pertanyaan siapa yang menanggung biaya dalam pengelolaan lahan tersebut. Beliau menjawab adapun yang menanggung semua biaya adalah semua anggota melalui koperasi, biaya apa pun itu dan pada dasarnya pihak koperasi pun meminjam uang ke Bank melalui perusahaan dan membayarnya perbulan dari hasil yang diperoleh koperasi setelah menjual hasil tandan buah segar kepada pihak perusahaan.

6. Informan VI

Informan selanjutnya adalah bapak Logen, ${ }^{27}$ bapak Logen sendiri bekerja sebagai petani yang sekarang berusia 42 tahun. Peneliti mengajukan pertanyaan apakah ada kendala selama proses bagi hasil berlangsung. Beliau menjawab kendala tentu ada, terutama waktu, waktu yang kadang tidak jelas kapan pembagiannya dan paling tidak anggota menerima hasilnya dalam waktu tiga bulan sekali, tetapi beliau menegaskan meskipun anggota menerima hasilnya tiga bulan sekali tetapi anggota menerima dengan jumlah yang cukup besar. Beliau menjelaskan dia yang hanya bekerja sebagai petani tentu tidak sabar untuk menunggu waktu pembagian tersebut, meskipun hasil yang diterimanya bisa disebut sebagai pendapatan tambahan tetapi setidaknya mampu menutupi kebutuhan hidupnya sehari-hari.

${ }^{25}$ Wawancara dengan Bapak Bastian selaku anggota koperasi Cempaka Biru Tanggal 07 Desember 2019.

${ }^{26}$ Wawancara dengan Bapak Karnan selaku anggota koperasi Cempaka Biru Tanggal 06 Desember 2019.

${ }^{27}$ Wawancara dengan Bapak Logen selaku ketua koperasi Cempaka Biru . Tanggal 06 Desember 2019. 


\section{Informan VII}

Informan selanjutnya adalah bapak Jahari ${ }^{28}$ yang bekerja sebagai wiraswasta yang sekarang berusia 44 tahun. Peneliti bertanya seputar sistem bagi hasil dan berapa jumlah yang didapat anggota setiap bagi hasil dilakukan. Beliau pun menjawab bahwa sistem bagi hasil ini dilakukan selama tiga bulan sekali, anggota akan langsung menerima hasilnya dari setiap pengurus kelompok, ada kelompok yang menerima dengan cara pengurus kelompok pergi ke rumahrumah anggota dan ada juga kelompok yang menerima hasil dengan mengambil langsung kepada pengurus kelompok di rumah atau ditempat yang disepakati pengurus kelompok dan setiap diakhir penerimaan hasil anggota akan menandatangani tanda bukti bahwa telah menerima hasil tersebut. Sedangkan untuk besarnya jumlah yang diterima tidak bisa diprediksikan.

Praktik bagi hasil pengelolaan lahan oleh koperasi pada dasarnya dapat membantu meningkatkan kesejahteraan dan taraf hidup anggotanya. Praktik bagi hasil pengelolaan lahan oleh koperasi ini disepakati oleh semua anggota yang bekerjasama dengan perusahaan, dimana koperasi sebagai pihak pertama harus memberikan jaminan bahwa seluruh tandan buah segar plasma hasil produksi dijual ke pabrik pengolahan minyak sawit pihak kedua atau perusahaan, sedangkan perusahaan sebagai pihak kedua wajib membeli tandan buah segar kebun plasma milik anggota koperasi.

Koperasi Cempaka Biru sendiri menyelenggarakan kegiatan usaha yang berkaitan dengan kegiatan-kegiatan anggotanya seperti usaha pengadaan sarana produksi pertanian, usaha simpan pinjam, usaha penampungan hasil produksi pertanian, usaha pertanian dan perikanan, usaha pengadaan sembako, usaha bahan bakar minyak dan usaha perkebunan kelapa sawit. Adapun yang menjadi usaha pokok koperasi adalah usaha perkebunan kelapa sawit. Usaha ini didasari karena pada dasarnya masyarakat di Kecamatan Sejangkung masih memiliki lahan yang cukup luas dan harus dimanfaatkan sebaik-baiknya, dan juga adanya bantuan dari pihak perusahaan untuk mengelola lahan dengan cara kerjasama, sehingga mempermudah kinerja koperasi terutama untuk menyalurkan atau menjual hasil tandan buah segar plasma, yang mana usaha pokok ini masih berlangsung sampai sekarang.

Koperasi Cempaka Biru mempunyai modal perusahaan tidak tetap yang diperoleh dari uang simpanan pokok, uang simpanan wajib, uang simpanan sukarela yang merupakan deposito serta uang pinjaman dan penerimaan lain yang sah. Modal dasar yang disetor pada saat pendirian koperasi ditetapkan sebesar Rp. 1.440.000 yang berasal dari simpanan pokok, simpanan wajib, dan modal penyertaan dari para pendiri koperasi serta modal pinjaman yang didapat dari pihak Bank. Pada dasarnya pembagian sisa hasil usaha di Koperasi Cempaka

${ }^{28}$ Wawancara dengan Bapak Jahari selaku anggota koperasi Cempaka Biru Tanggal 06 Desember 2019. 
Biru sama dengan koperasi pada umumnya. Hanya saja karena koperasi bekerja sama dengan pihak perusahaan maka pihak koperasi akan terlebih dahulu melakukan bagi hasil dengan pihak perusahaan dengan persentase jumlah pembagian 50:50 yang mana pembagian ini telah diketahui semua anggota koperasi dan setelah itu koperasi akan membagikan sisa hasil usaha kepada anggotanya.

Adapun pembagian hasil di Koperasi Cempaka Biru ini anggota menerima sisa hasil usaha dalam jangka waktu menurut kesepakatan tiga bulan sekali sesuai anggaran dasar koperasi yang telah disepakati dalam rapat anggota koperasi, tetapi meskipun telah ditentukan terkadang anggota menerima sisa hasil usaha tidak sesuai dengan waktu yang telah disepakati. Besarnya jumlah sisa hasil usaha yang diterima oleh anggota koperasi tidaklah tetap, sesuai pendapatan koperasi dari penjualan tandan buah segar dan juga sisa perawatan kebun serta sisa biaya lainnya.

Menurut Undang-Undang No. 25 Tahun 1992 Pasal 45 bahwa sisa hasil usaha koperasi merupakan pendapatan koperasi yang diperoleh dalam satu tahun buku dikurangi dengan biaya, penyusutan, dan kewajiban lainnya termasuk pajak dalam tahun buku yang bersangkutan. Sisa hasil usaha setelah dikurangi dana cadangan, dibagikan kepada anggota standing dengan jasa usaha yang dilakukan oleh masing-masing anggota dengan koperasi, serta digunakan untuk keperluan pendidikan perkoperasian dan keperluan lain dari koperasi sesuai dengan keputusan rapat anggota dan besarnya pemupukan dana cadangan ditetapkan dalam rapat anggota.

Berdasarkan penjelasan Undang-Undang No. 25 Tahun 1992 Pasal 45 tersebut bahwa sisa hasil usaha koperasi merupakan pendapatan koperasi yang diperoleh dalam satu tahun buku, sedangkan dalam Anggaran Dasar Koperasi Cempaka Biru hasil yang dibagikan merupakan pendapatan koperasi dalam jangka waktu tiga bulan buku, jadi jika pun Koperasi Cempaka Biru terlambat membagikan sisa hasil usaha kepada anggotanya yang terhitung masih dalam satu tahun buku maka koperasi tersebut tidak melanggar Undang-Undang No. 25 Tahun 1992 Pasal 45 tentang Sisa Hasil Usaha, hanya saja koperasi tetap melanggar Anggaran Dasar Koperasi Cempaka Biru yang telah disepakati semua anggotanya dalam rapat anggota.

Meskipun demikian Koperasi Cempaka Biru telah memenuhi tujuannya sebagai berikut:

1. Simpanan pokok adalah sejumlah uang yang wajib dibayarkan oleh anggota pada saat masuk menjadi anggota. Koperasi Cempaka Biru menetapkan simpanan pokok sebesar Rp. 50.000 .

2. Simpanan wajib adalah jumlah simpanan tertentu yang harus dibayarkan oleh anggota kepada koperasi dalam waktu dan kesempatan tertentu, misalnya tiap bulan dengan jumlah simpanan yang sama untuk setiap 
bulannya. Koperasi Cempaka Biru menetapkan simpanan wajib kepada anggotanya sebesar Rp. 10.000/bulan.

3. Dana cadangan adalah sejumlah uang yang diperoleh dari penyisihan sisa hasil usaha, yang dimaksud untuk pemupukan modal sendiri, pembagian kepada anggota yang keluar dari keanggotaan koperasi, dan untuk menutup kerugian koperasi bila diperlukan. Dalam Anggaran Dasar Koperasi Cempaka Biru besarnya presentasi dana cadangan adalah 40\% dari sisa hasil usaha.

4. Koperasi Cempaka Biru sendiri dapat dikatakan memenuhi tujuan koperasi dimana pihak koperasi sebagai pengelola menghimpun dana dari anggota koperasi yang disebut simpanan pokok anggota dan menyalurkan kembali kepada anggotanya dalam bentuk bagi hasil Sisa Hasil Usaha yang didapat dari keuntungan menjual hasil lahan berupa kelapa sawit.

Adapun dalam Anggaran Dasar Koperasi Cempaka Biru sisa hasil usaha yang diperoleh dari usaha yang diselenggarakan untuk anggota dibagi sebagai berikut:

1. $40 \%$ untuk cadangan modal

2. $30 \%$ untuk anggota

3. $15 \%$ untuk dana pengurus dan pengawas

4. $5 \%$ untuk dana karyawan

5. $5 \%$ untuk dana pendidikan dan pembinaan

6. $2,5 \%$ untuk dana sosial

7. $2,5 \%$ dana Pembangunan Daerah Kerja

Besarnya persentase pembagian sisa hasil usaha tersebut telah disepakati semua anggota Koperasi Cempaka Biru dalam Anggaran Dasar koperasi yang tertuang dalam akta pendirian Koperasi Cempaka Biru.

Tinjauan Hukum Islam Terhadap Praktik Bagi Hasil Pengelolaan Lahan Oleh Koperasi Cempaka Biru

Koperasi (syirkah) merupakan salah satu kegiatan muamalah yang diperbolehkan dalam Islam selama tidak ada pihak yang dirugikan. Adapun landasan diperbolehkannya Syirkah berdasarkan Alquran surat Shad ayat 24 yaitu:

"Dan Sesunggubnya kebanyakan dari orang-orang yang berserikat itu sebahagian mereka berbuat zalim kepada sebahagian yang lain, kecuali orang-orang yang beriman dan mengerjakan amal yang saleb; dan Amat sedikitlah mereka ini". dan Daud mengetahui bahwa Kami mengujinya; Maka ia meminta ampun kepada Tuban-nya lalu menyungkur sujud dan bertaubat.

Walaupun diperbolehkan dalam melakukan muamalah, perlunya memahami tentang aturan-aturan dalam bermu'amalah salah satunya yaitu harus adanya akad, karena kesalahan dalam melakukan transaksi muamalah sering 
merujuk pada akad antara kedua belah pihak. Dalam Syirkah harus ada akad kerja sama antara dua pihak atau lebih untuk terbentuknya suatu usaha tertentu. Pelaksanaan bagi hasil harus sesuai kesepakatan bersama agar tidak terjadi kesalahpahaman sesama anggota dan tidak adanya pihak yang merasa dirugikan. Apabila sistem bagi hasil tersebut telah sesuai kesepakatan bersama dan memenuhi syarat dan rukun akad serta tidak ada pihak yang merasa dirugikan maka hukumnya boleh menurut syariah.

Berdasarkan praktik bagi hasil pengelolaan lahan oleh koperasi terdapat unsur tolong menolong (ta'awnn) antara pihak pengurus koperasi dan anggota koperasi, dimana pihak koperasi diberi kepercayaan untuk mengelola lahan dan anggota sendiri mempunyai modal berupa lahan yang akan dikelola oleh koperasi. Sebagaimana firman Allah SWT dalam Al-Qur'an surat Al-Maidah ayat 2:

'Hai orang-orang yang beriman, janganlah kamu melanggar syi'ar-syi' ar Allah dan jangan melanggar kehormatan bulan-bulan baram, jangan (mengganggu) binatang-binatang had-ya, dan binatang-binatang qalaa-id, dan jangan (pula) mengganggu orang-orang yang mengunjungi Baitullab sedang mereka mencari kumia dan keredhaan dari Tuban-nya dan apabila kamu telah menyelesaikan ibadah haji, Maka boleblah berburu. dan janganlah sekali-kali kebencian(mu) kepada sesuatu kaum karena mereka menghalang-halangi kamu dari Masjidil Haram, mendorong kamu berbuat aniaya (kepada mereka). dan tolongmenolonglah kamu dalam (mengerjakan) kebajikan dan takwa, dan jangan tolong-menolong dalam berbuat dosa dan pelanggaran. dan bertakwalah kamu kepada Allah, Sesunggubnya Allah Amat berat siksa-Nya".

Berdasarkan pelaksanaan bagi hasil pengelolaan lahan oleh Koperasi Cempaka Biru Kecamatan Sejangkung, bagi hasil ini menggunakan akad Mukhabarah yaitu kerja sama pengolahan pertanian antara pemilik lahan dan penggarap, dimana pemilik lahan memberikan lahan pertanian kepada si penggarap untuk ditanami dan dipelihara dengan imbalan tertentu (persentase) dari hasil panen dan benihnya berasal dari penggarap. Bentuk kerja sama antara pemilik tanah dan penggarap dengan perjanjian bahwa hasilnya dibagi menurut kesepakatan. Biaya dan benihnya dari pemilik tanah.

Berdasarkan praktik bagi hasil pengelolaan lahan oleh koperasi, koperasi disebut sebagai penggarap karena koperasi yang mengelola lahan sedangkan anggota disebut sebagai pemilik lahan. Adapun dalam pelaksanaan bagi hasilnya rukun mukbabarah yaitu pemilik tanah, penggarap, objek akad serta ijab dan kabul. Adapun syarat mukhabarah adalah pemilik dan penggarap kebun orang yang telah dewasa, benih yang akan ditanam harus jelas dan menghasilkan, lahan merupakan lahan yang menghasilkan dan jangka waktu harus jelas menurut kebiasaan. Apabila praktik bagi hasil pengelolaan lahan oleh koperasi telah memenuhi rukun dan syarat yang telah disebutkan sebelumnya maka praktik bagi hasil demikian sudah sah dan sesuai syariah. 
Berdasarkan objek penelitian tentang praktik bagi hasil pengelolaan lahan oleh Koperasi Cempaka Biru di Kecamatan Sejangkung dalam pelaksanaannya peneliti menemukan adanya ketidakpastian waktu dalam pembagian sisa hasil usaha yang dilakukan oleh koperasi kepada anggotanya, hal ini menyebabkan akad menjadi cacat karena adanya salah satu syarat akad yang tidak terpenuhi. Sebagaimana firman Allah SWT dalam Al-Qur'an surat AlMaidah ayat 1 yaitu:

"Hai orang-orang yang beriman, penubi lah akad-akad itu".

Islam menekankan bahwa dalam melaksanakan suatu perikatan atau akad, maka harus memenuhi hukum akad yang merupakan unsur dari akad itu sendiri (rukun dan syarat akad). Keduanya sama-sama menentukan sah atau tidaknya suatu transaksi. Berdasarkan penjelasan yang dipaparkan, dapat diketahui bahwa salah satu akad pada Koperasi Cempaka Biru Kecamatan Sejangkung mengandung unsur gharar (ketidakpastian) karena dalam pembagian hasil usahanya koperasi tidak menepati waktu pembagian yang telah disepakati sebelumnya.

Berdasarkan penjelasan yang telah dipaparkan, peneliti menarik kesimpulan bahwa salah satu akad dalam praktik bagi hasil pengelolaan lahan oleh Koperasi Cempaka Biru di Kecamatan Sejangkung dilarang oleh syara' dan mengandung unsur gharar (ketidakjelasan), karena adanya ketidakpastian waktu dalam pembagian hasil sisa usaha oleh koperasi kepada anggotanya.

\section{Penutup}

Praktik bagi hasil pengelolaan lahan oleh Koperasi Cempaka Biru yang dilakukan di Kecamatan Sejangkung terdapat ketidakjelasan waktu dalam pembagian sisa hasil usahanya meskipun demikian praktik tersebut tidak bertentangan dengan Undang-Undang No. 25 Tahun 1992 Pasal 45 yang menjelaskan Sisa Hasil Usaha. Berdasarkan hasil penelitian yang dilakukan oleh peneliti bahwa tinjauan hukum Islam terhadap praktek bagi hasil pengelolaan lahan oleh Koperasi Cempaka Biru di dilarang oleh syara' karena mengandung unsur gharar. ), karena adanya ketidakpastian waktu dalam pembagian hasil sisa usaha oleh koperasi kepada anggotanya padahal kesepakatan dalam perjanjian bagi hasil harus sesuai dengan waktu yang telah ditentukan.

\section{Daftar Pustaka}

Abdi Widjaya, Konfigurasi Akad dalam Islam, Makassar: Alauddin University Press, 2014

Abdul Rahman Ghazali, Fiqih Muamalat, Jakarta: Kencana Prenada Media Group, 2010

Abdul Rahman Ghazali, Fiqih Muamalat, Jakarta: Kencana, 2010 
Abdur Rahman al-Jaziri, Fiqh Empat Mazhab, Terj. Moh. Zuhri, Jakarta: Pustaka Al-Kautsar, tt

Atabik Ali Ahmad Zuhdi Muhdlor, Kamus Kontemporer, Yogyakarta: Yayasan Ali Maksum Krapyak Yogyakarta, 1999

Azharudi Latift, Fiqhi Muamalat, Jakarta: Kencana, 2010

Departemen Agama RI, al-Qur'an dan Terjemahnya, Diponegoro: Al- Hikmah, 2010

H. Minhajuddin, Fikih Mu'amalah dalam Islam, Makassar: Alauddin University Press, 2011

Husain Al-Habsyi, Kamus Al-kautsar (Arab-Indonesia), Surabaya: Assegaff, 1977

Miftahul Jannah, Isna Yuningsih, Rabiatul Adawiyah, Jurnal Ekonomi Mulawarman Vol 3, No. 4 Tahun 2018, Pengaruh Sistem Bagi Hasil Perkebunan Kelapa Sawit Terhadap Kesejahteraan Masyarakat (Studi di Desa Tengin Baru Kecamatan Sepaku Kabupaten Penajam Paser Utara)

Munir dan Sudarsono, Dasar-Dasar Agama Islam, Jakarta: Rineka Cipta, 2001

Nasroen Haroen, Fiqih Muamalah, Jakarta: Gaya Media Pratama, 2000

Sulaiman Rasyid, Fiqih Islam (Hukum Fiqh), Jakarta: Sinar Baru, 1994

Syafei, Rachmat. Fiqih Muamalah, Bandung: CV Pustaka Setia, 2006

Zaki Fuad Chalil, Pemerataan Distribusi Kekayaan dalam Ekonomi Islam, Jakarta: Erlangga, 2009 
158 | Al-Istinbath: Jurnal Hukum Islam, Vol.5, No.1, 2020

Halaman sengaja dikosongkan 